\title{
4
}

\section{IN SEARCH OF CIVIC PARTICIPATION}

\author{
Advocacy tactics in the energy and \\ environmental sector in post-communist Europe
}

\author{
Szczepan Czarnecki
}

\section{Introduction}

After the fall of communism, a body of literature emerged focusing on the transformation of CEE. Since CEE countries share a legacy of environmental neglect and highly inefficient energy usage, their energy and environmental policies were a frequently discussed topic. The transition heralded different sets of reforms with different degrees of success. The transformation of the energy sector resulted in steps to use less energy and cut emissions, which was partially facilitated by mass bankruptcies of energy-intense industries. Yet energy dependency and the low diversification of energy supplies constituted significant obstacles. Common to our three analyzed countries, the Czech Republic, Poland and Slovenia, are limited deposits of natural resources, increasing energy competition and prices as well as dependence on energy imports. Against this background, they are pursuing multiple goals aimed at diversified energy sources, increasing energy efficiency and forming regional energy markets (Sprūds, 2010).

As a result, energy advocacy interest groups have proliferated in the region, opening up many new fields of action - and research. Despite the difficult legacy of interest groups in CEE (Kubik, 2005), environmental groups soon would become integral to the democratic process by engaging in decision-making and policy implementation in different arenas. Simultaneously, the growing importance of energy security (often based on fossil fuels) and the strong position of organizations associated with the production of fossil fuels shaped different levels of policy-making. This has significantly enhanced our possibilities to explore interest groups in CEE. In this chapter, I focus on the wide range of interest groups (IG) lobbying strategies that are being used to achieve political results in line with the groups' preferences. 


\section{Background}

In the political context, there are many paths to influence the policy-making process, from which we can distinguish direct (administrative or parliamentary) or indirect (media and mobilization) forms of advocacy to maximize political influence. Taking into account the diversity of goals and advocacy strategies, I explore how lobbying strategies of interest organizations vary by type (sectional and cause groups), strategic goals regarding environmental and energy policy, and the country of origin. The literature on interest groups indicates that organization type is an important determinant of lobbying behavior. Various classifications have been provided, for example, "concentrated vs. diffuse" interests based on Olson's collective action theory (Olson, 1965) and "sectional vs. idealistic", groups with "corporative resources versus public interest groups" (Binderkrantz, 2005, 2008). Despite terminological differences, these classification schemes largely correspond to each other.

Interest groups included in this study operate in two "combined" policy areas, energy and environment, but also display diversity in other ways. The first difference refers to the structure and focus of the groups. Some groups are idealistic organizations with individual membership working toward idealistic goals such as environmental protection, while other IGs representing business groups formed to obtain material benefits for specific groups of people (Binderkrantz, 2005). These differences put these groups in different situations during the advocacy process.

Interest group activity is always affected by the political environment in which groups operate. As a result, the effective study of public interest groups must situate them in a larger political context (Meyer \& Imig, 1993). It has to be outlined that the three countries analyzed in this study are significantly different due to their level of political coordination as well as their energy sectors. Poland constitutes a relatively liberal market economy with a weak degree of coordination, thus providing the foundations for a more pluralist interest group landscape. However, elections are publicly funded and extensive lobbying regulations exist, which may stymie the influence of interest groups (McGrath, 2008). The Czech Republic is also a highly open market economy with privately funding elections and weaker lobbying regulations (McGrath, 2008; Šimral, 2015) and thus potentially more penetrable by organized interests. Slovenia is the most coordinated market economy in CEE (Avdagić \& Crouch, 2006; Bohle \& Greskovits, 2012), and as an ex-Yugoslav country, the Slovenian economy has historically been highly decentralized and enjoyed considerable autonomy from the state.

Despite similar attempts at energy supply diversification, the energy and environmental policies of Poland, Czechia, and Slovenia also substantially vary. According to the European Environment Agency (EEA), Poland has one of the highest levels of contamination by carcinogenic benzopyrene among all EU countries (Skoczkowski et al., 2018). Excessive atmospheric air pollution occurs on over $20 \%$ of Polish territory due to its power industry based on coal and lignite, wood, and litter for energy production in households, the limited number of waste gas 
purifying installations, and automobile traffic (see Chapter 10 in this volume). The spatial distribution of pollutant emissions is very uneven - the highest level is found in areas of large urban agglomerations and major industrial districts, e.g., the Silesian Voivodeship, where $20 \%-25 \%$ of national emissions of sulfur dioxide (SO2), nitrogen oxides, and dust are concentrated or Lesser Poland (Małopolska), one of the most polluted EU regions. Dependence on Russian energy supplies has greatly shaped Polish energy policy and the direction of its implementation. As with other CEE countries, Poland faced issues regarding energy security. In 1997, an Energy Law Act was presented, in which energy security was defined as an aim of the state economy to meet the demands of citizens as recipients for energy, taking into account environmental or economic requirements. The newest strategic plan for energy by 2040 assumes that the Polish energy mix will be still based on coal (50\%-60\%), renewables $(21 \%-23 \%)$, and planned nuclear power.

In contrast to Poland, nuclear energy accounts for approx. $40 \%$ of Czech energy production. It is also well known for its extensive surface mining of brown coal in the Sokolov and Most Basin. The coal mined in these quarries supplies coalfired power plants, which are the source of approximately $40 \%$ of the electricity produced in the Czech Republic. According to the EEA Report No. 12/2018, the northeastern part of the Czech Republic is more affected by air pollution than the rest of the country, but Southern Moravia is also struggling with a high degree of air pollution despite the absence of the coal industry. Moravia-Silesia is the traditional industrial center specialized in metallurgy and black coal mining and has the highest degree of air pollution. However, the governmental strategy is to phase most of it out over the next 20 years, replacing part of it with new nuclear power plants as well as gas, renewables, and energy imports.

The Slovenian energy sector is comparatively small, with oil constituting the main energy source (45\%). Electricity generation is equally divided between hydropower (36.5\%), nuclear energy (36.5\%), and coal (21.6\%). Trends in energy policy go in the direction of maintaining the status quo (Živčič \& Tkalec, 2019). Renewables still contribute a limited share of electricity generation, with solar accounting for less than $2 \%$, and wind energy even less $(0.02 \%)$, which makes Slovenia the EU country with the smallest forecasted concentration of wind power in electricity consumption in 2020 (Živčič \& Tkalec, 2019). Slovenia's vision for the energy sector is gradually to transition to low-carbon energy sources by focusing on efficient energy consumption, renewables (RES), and the development of active electricity distribution networks. This strategy will likely lead to a strong reliance on nuclear energy and further development of hydroelectric power (see Czarnecki, Piotrowska, \& Riedel in this volume).

\section{Theoretical framework and hypotheses}

Interest groups rely on a wide repertoire of tactics for influencing public policies. They may coalesce with other like-minded actors, employ inside or outside 
tactics, target specific institutional venues at multiple levels of government, and employ different types of information (Binderkrantz 2005, De Bruycker, 2014). While tactics may be conceptually classified as belonging to either an inside or outside strategy, it is an empirical question whether they coalesce into more overarching strategies in the behavior of NGOs (Dellmuth \& Tallberg, 2017). Efforts to influence policy-making through the media or public support are referred to as outside lobbying (Binderkrantz, 2005). Inside lobbying, by contrast, refers to attempts to influence policy-makers through direct interaction, e.g., by means of advisory boards, consultations, or personal contacts (Beyers, 2004, p. 213). The literature suggests that group type is an important determinant of organizations' lobbying behavior (Maloney et al., 1994). There is a common distinction between groups depending on whether they work to obtain goods that will selectively and materially benefit group members or not (Berry, 1977). According to Jeffrey M. Berry, a public interest group is one that seeks a collective good, which will not selectively or materially benefit the membership or activists of the organization (Berry, 1977, p. 7). This allows us to divide the studied groups into groups with a broader idealistic character and groups working to meet the needs (certain goods) of their members. Binderkrantz (2005) emphasizes that interest organizations drawing their members from particular groups of people often will find themselves in a monopoly situation when it comes to supplying these people with certain goods. Organizations with idealistic goals more often will attract their members from different parts of society; the welfare of the members will not depend directly on the success of the group, and competition between groups will occur more often (Binderkrantz, 2005; Dunleavy, 1991). For groups working on such issues, it is particularly important to constantly mobilize their membership base and to inform the public regarding the disputed issue (Binderkrantz, 2005; Gais \& Walker, 1991; Streeck \& Kenworthy, 2005). Only constant debate and the buildup of peer pressure can solve the collective action problem (Brennan, 2009). Binderkrantz points out that idealistic groups are thus in a situation, in which they need to continually reinforce the loyalty of their members. They are therefore expected to more often pursue outside lobbying tactics (e.g., protesting, holding press conferences, making public speeches, and organizing petitions), because the visibility of such strategies signals to members and potential members that the group is effective and worth supporting (Binderkrantz, 2008). Thus, I hypothesize:

Hypothesis 1: Idealistic interest groups are more likely to rely on outside lobbying tactics than sectional interest groups.

Advocacy organizations can strategically select one or more venues for lobbying in a system providing multiple access points to lawmakers in both national and local governments. However, the specificity of the advocacy goals itself cannot be neglected either. Wilson (1973) argued that when the debated issue is divisible, groups are more likely to seek direct interaction with policy-makers. By 
contrast, when pursued goals are non-divisible, organizations are more likely to use outside lobbying tactics. I hypothesize:

Hypothesis 2: Groups pursuing a non-divisible goals are more likely to "go public", while groups lobbying for divisible goals are more likely to use direct lobbying techniques.

Moreover, the goals organized interest groups pursue may also shape their lobbying strategies. Baumgartner et al. (2009) argued that a determinant of success is whether the group goal is to change the policy or rather to keep the status quo. Groups protecting the status quo benefit from the existence of a so-called coalition of the status quo, which prevents change by controlling access to the political system (Binderkrantz \& Krøyer, 2012). Therefore, I distinguish between groups pursuing to uphold or change existing policies and argue that groups seeking to protect the status quo will mainly approach bureaucrats and politicians, while groups seeking to dismantle the status quo seek to widen the scope of the policy conflict by going public (Schattschneider, 1960) and engaging in various forms of public protest (Grant, 2000). Therefore:

Hypothesis 3: Groups seeking to protect the status quo will more likely approach bureaucrats and politicians, while groups seeking to dismantle the status quo are more likely to go public.

Finally, lobbying regimes and thus the broader political environment in which they operate may also shape strategies (Meyer \& Imig, 1993). Here, I assume that privately funded elections (Czechia) may give more space to the business groups, while in the case of Poland and Slovenia, where elections are publicly funded, groups will choose outsider strategies more often to foster stronger links between society and political parties.

Hypothesis 4: Privately funded elections are more likely to give more space to business groups, while publicly funded elections will more likely result in outside strategies to foster stronger links between society and political parties.

\section{Methods}

To gather data suitable to the research question, I drew on population ecologies of energy and environmental groups in the three selected countries. Using the official registries published by the Ministry of the Interior of the Czech Republic, Ministry of Justice of Poland, and Ministry of the Interior of Slovenia, searches were conducted with every combination of words for organizations related to the third sector categories in the three countries. ${ }^{1}$ Based on our survey methodology 
outlined in the Introduction and Annex, survey responses were collected from organizations which met three criteria: (1) they are officially registered, (2) they are non-profit and non-governmental, and (3) they deal with energy or environmental policy. Organizations received a set of questions regarding lobbying and access as well as their internal structure, professionalization, and resources. The sample for this specific analysis includes 132 organizations.

Referring to the wide range of lobbying strategies used to achieve political results in line with their preferences, I analyzed and described specific lobbying tactics. As there are various ways to influence the policy-making process, from which we can distinguish direct or indirect forms of advocacy, the dependent variable is divided into eight variables covering parliamentary, administrative, media, and mobilization strategies. For the purpose of this specific analysis, groups were asked, e.g., to indicate if they used the specific tactics in energy policy in terms of direct, e.g., contacts with political parties and government and indirect: a) media (using traditional media as TV, radio and newspapers, social media) and b) mobilization strategies such as protest, petitions, and common positions or initiatives. Positive responses for a given form of lobbying were coded as 1 , and negative answers were coded as 0 .

Group type. According to the literature, many variables, such as institutional structures, group characteristics, and issue-specific factors, can condition IG tactics (Dür \& De Bièvre, 2007). Some scholars differentiate organizations with corporative resources from public interest groups, NGOs, and business interests (Beyers et al., 2008; Binderkrantz et al., 2015). Others distinguish sectional from cause groups (Stewart, 1958). However, these type classifications largely overlap. This chapter employs a typology differentiating groups as sectional organizations that are formed to obtain material benefits for specific groups of people and represent special interests that create concentrated costs and benefits for their supporters, e.g., business groups, trade unions and cause groups that are more idealistic, while acting for the public interest and public goods, e.g., energy consumers, environmentalists, and ecologists (Klüver \& Saurugger, 2013). To measure which organizations are idealistic or sectional interests, I created a dichotomous variable that takes the value 0 for public interest idealistic groups and 1 for sectional organizations (see Table 4.1).

Group policy goals may also vary considerably. To measure whether organization goals are divisible or non-divisible, I conducted qualitative textual analysis based on the highlighted expectations of the IGs and the degree of change

TABLE 4.1 Cause and sectional groups

\section{Cause groups}

Sectional groups

- civic IGs promoting clean, sustainable, renewable energy - energy producers

- civic IGs promoting energy efficiency

- civic IGs representing energy consumers

- associations of energy suppliers 


\section{Divisible Goals}

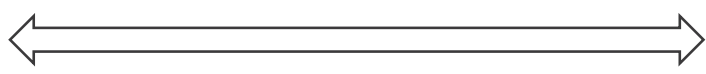

Flexible
Non-divisible goals

Absolute

FIGURE 4.1 IG goals division

sought. The analysis was conducted using websites of the organizations (status and goals sections). If organizations emphasized an absolute goal such as the need for a complete change of the implemented policy, total reduction of fossil fuels use, or, by contrast, maximization of the use of fossil fuels in terms of electricity production, the goals were coded as non-divisible with a given value 1 . In cases when groups emphasized the need for reduction instead of, e.g., absolutely urgent decarbonization, goals were coded as divisible with a given value of 0 . Applying the same logic as previously, IGs focusing on change were coded with 1 and those aiming to keep the status quo were given the value 0 .

In order to measure lobbying tactics, I conducted a binary logistic regression. The most important feature of logistic regressions is that the predicted variable is dichotomous; that is, it takes two values 0 and 1 for the occurrence or absence of a certain phenomenon. Binary logistic regression is used to predict the odds of being a case based on the values of the independent variables. The odds are defined as the probability of comparing the odds of the two events. The odds of an event are the probability that the event occurs divided by the probability that the event does not occur. I used the value 0 for the absence of the predicted variable and 1 for its presence (e.g., if the organization applies protest tactics, I added 1, if not 0 ). Collinearity was tested by checking the pairwise correlation of the independent variables, thus providing no evidence of collinearity. To test whether specific lobbying regimes result in different lobbying strategies, I conducted Pearson's chi-square test of independence to determine whether there is a significant association between the two variables.

\section{Data analysis}

The dependent variable(s) are forms of lobbying by IGs operating in energy and environmental policy. To avoid a simple dichotomous division between insider and outsider groups, while measuring direct (inside) and indirect (outside) lobbying strategies, I divided lobbying tactics into eight different forms of lobbying. The division is related to the direct strategies: a) parliamentary lobbying when certain lobbyists contact directly political representatives (politicians and parties), b) administrative: when lobbyists contact relevant ministries and public servants (indicated as government) and indirect strategies when lobbyists use media strategies such as c) social media, d) traditional media, and e) PR campaigns and when implemented strategies are based on mobilization as f) petitions, 
g) protests, and h) common positions. In accordance with the hypotheses, I start with a short reflection of different dimensions of lobbying strategies. The first step in the analysis of group strategies aims to gain a clear picture of the extent to which different tactics are deployed by IG due to the group type, their goals, and countries of origin.

As shown in Figure 4.2, differences exist between specific lobbying tactics among two indicated groups. The most visible difference concerns protests and conducting petitions. Only $7.83 \%$ of the sectional IGs reported protest as part of their advocacy strategies, while idealistic IGs indicated protest much more often (67.63\%). This means that almost two out of three idealistic groups operating in energy and environmental sector use protest to influence the political debate. Public interest groups are also much more active in holding petitions, as $73.10 \%$ of the idealistic IGs indicated using petitions as an advocacy strategy. Like in the previous case, specific interest groups are much less involved in this form of activity, as only $10.67 \%$ of specific groups from the three analyzed countries indicated petitions as their preferred form of advocacy. Direct forms of lobbying commonly are used in both analyzed groups. 57\% of analyzed idealistic groups reported that they contact political parties, and $60.1 \%$ the government. It seems that the governmental and parliamentary strategy is popular among public interest organizations. However, these forms are used even more often by the sectional interest groups. $88.6 \%$ of sectional IGs reported using administrative strategies and $90.77 \%$ indicated using the parliamentary strategy. The media strategy seems to be more popular among public interest groups. $86 \%$ of idealistic groups use social media, $69.7 \%$ traditional media, and $69.7 \%$ public relations campaigns when trying to influence the policy process.

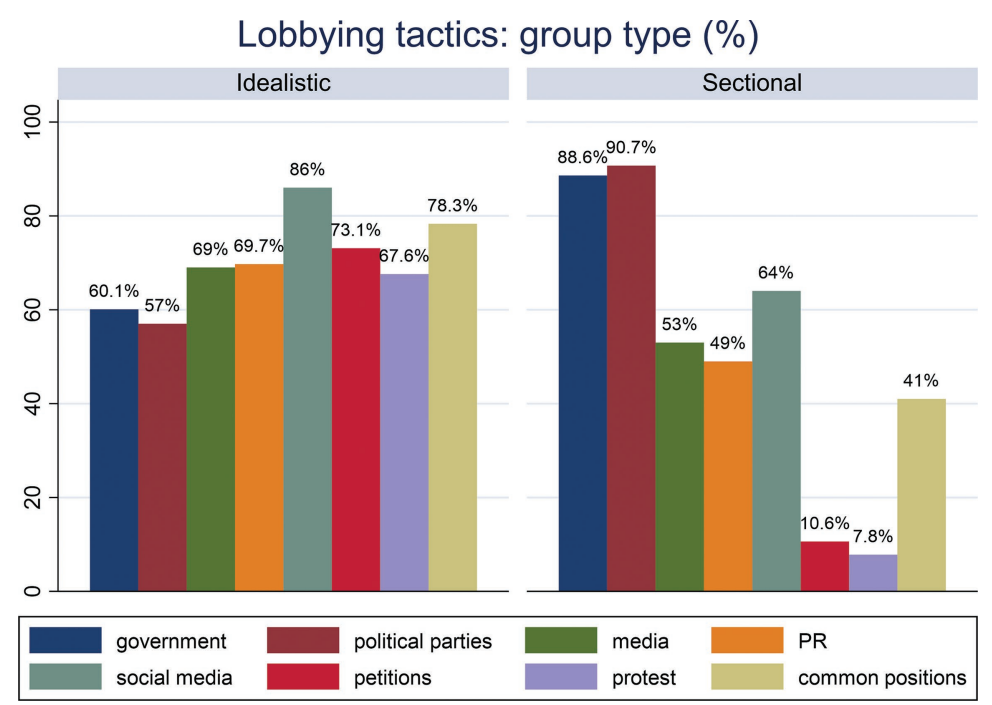

FIGURE 4.2 Lobbying tactics: group type (\%) 
When it comes to strategic goals, the analysis shows that interest groups with absolute, non-divisible goals attach much more importance to indirect forms of lobbying than groups with divisible goals (Figure 4.3). The data reveal that groups with the non-debatable goals understood as "all or nothing" use outside strategies more often than groups with more divisible goals. "Absolute goals groups" more frequently hold petitions (46.6\%) and protests (43.74\%) than groups with more debatable "more or less" goals. However, for both analyzed types of goals, direct strategies are used often. Even as groups with divisible goals more frequently reported parliamentary (89.41\%) and administrative (86.2\%) strategies, it is visible that these strategies are still important and often used by "non-divisible goals" groups (66.19\% parliamentary) and (62.13\% government).

As shown in Figure 4.4, the lobbying strategies moderately differ between countries. The data show that IGs from the Czech Republic indicated indirect strategies less frequently than groups surveyed in Poland and Slovenia. Also, the governmental strategy seems to be less attractive for Czech IGs (64.6\%) than for their counterparts in Poland and Slovenia. By contrast, groups in Czechia reported contacting political parties more often (75\%) than groups from Slovenia (69.5\%), but less than Poland (79.45\%).

Applying a chi-square test, I analyzed whether there is a significant relationship between the types of groups in the three countries and the usage of specific lobbying tactics as expected in hypothesis 4 . In the case of Poland, the p-value in two cases of indirect tactics, i.e., protest and petitions, is lower than our chosen

\section{Lobbying tactics: goals (\%)}

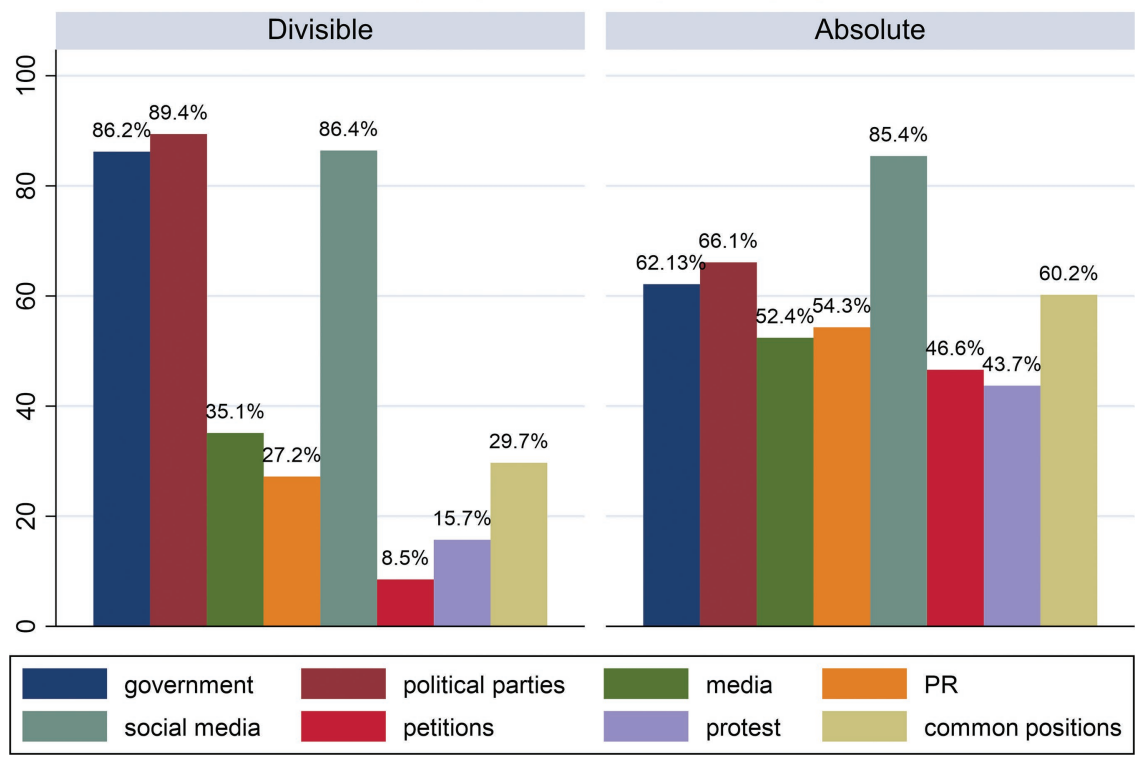

FIGURE 4.3 Lobbying tactics: goals (\%) 


\section{Lobbying tactics: countries (\%)}

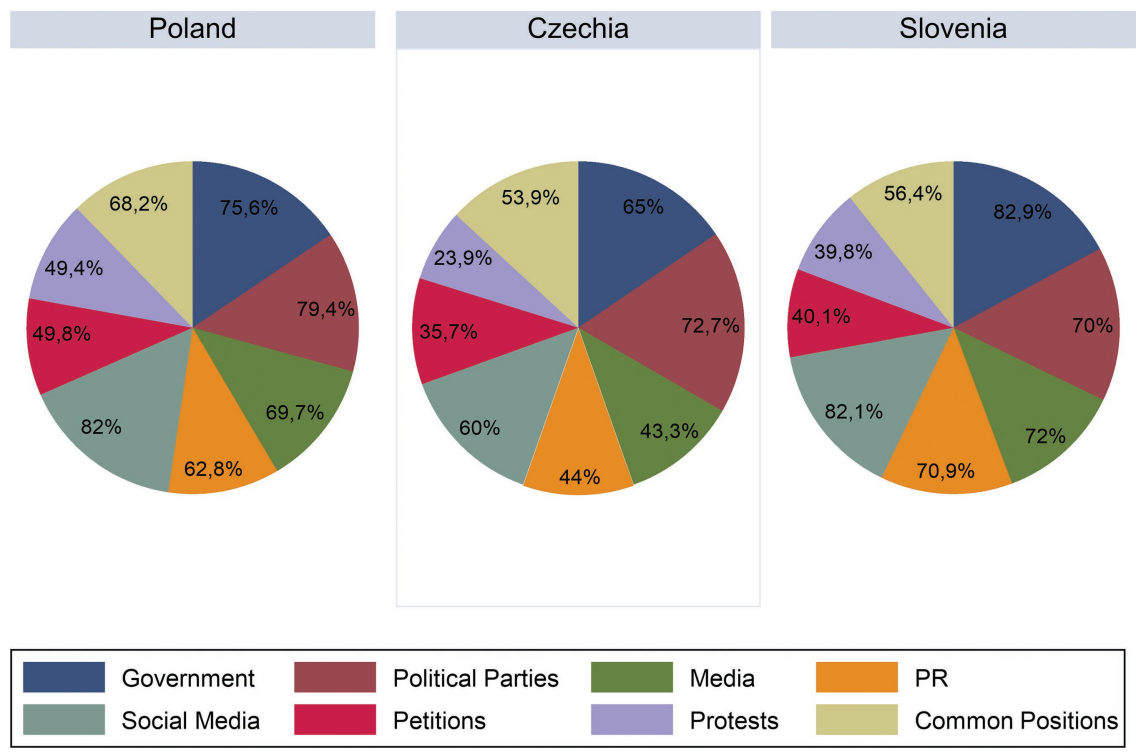

FIGURE 4.4 Lobbying tactics: country (\%)

significance level $(\alpha=0.05)$. I conclude that there is an association between organization type and outside lobbying tactics. There is a stronger tendency for idealistic groups to organize petition campaigns and protest. I also found that both traditional tactics and social media are favored by idealistic groups compared to sectional organizations. Direct lobbying tactics seem to be less dependent on group type. However, in the Polish case, contacting the government and political parties is more common for sectional IGs. The results for Czech organizations are somewhat different from those in Poland. Data suggest stronger intergroup differences than in the Polish case. Sectional groups are more focused on direct lobbying tactics, i.e., contacting political parties and government, while idealistic groups are more geared toward outside activities such as protest, petitions and common positions. Yet again, for Slovenia, I found that idealistic organizations, like in Poland, more frequently use outside lobbying methods, while sectional groups prefer contacting politicians. However, in this case, the $\mathrm{p}$-level is higher than the chosen significance level $(\alpha=0.05)$. Thus, the results partially confirm hypothesis 4 . Indeed in the Czech case, where elections are privately funded, sectional groups have more space to use direct lobbying strategies. Yet in each case, the distinction between groups by type suggests that even in Poland and Slovenia, where elections are publicly funded, sectional groups are more focused on direct lobbying, while indirect activities such as protest and 
TABLE 4.2 Pearson's chi-square test results for lobbying tactics by group type in countries

\begin{tabular}{|c|c|c|c|c|c|}
\hline & Value & $d f$ & $p$ & $\%$ Idealistic & $\%$ Sectional \\
\hline \multicolumn{6}{|l|}{ Poland } \\
\hline Government & 1.625 & 1 & 0.336 & 61.3 & 89.9 \\
\hline Political parties & 1.926 & 1 & 0.165 & 71.6 & 87.3 \\
\hline Mass media & 4.523 & 1 & 0.033 & 86.4 & 53 \\
\hline Social media & 4.788 & 1 & 0.029 & 100 & 80 \\
\hline Public relations & 1.915 & 1 & 0.166 & 72.7 & 53 \\
\hline Protest & 20.442 & 1 & 0.000 & 86.4 & 12.5 \\
\hline Petitions & 19.6 & 1 & 0.000 & 85.7 & 14 \\
\hline Common positions & 5.639 & 1 & 0.018 & 86.4 & 50 \\
\hline \multicolumn{6}{|l|}{ Czechia } \\
\hline Government & 26.705 & 1 & 0.000 & 41.7 & 87.40 \\
\hline Political parties & 21.565 & 1 & 0.000 & 48.4 & 97 \\
\hline Mass media & 0.066 & 1 & 0.798 & 40.6 & 44 \\
\hline Social media & 3.715 & 1 & 0.054 & 65.6 & 40 \\
\hline Public relations & 2.523 & 1 & 0.112 & 54.8 & 33.3 \\
\hline Protest & 11.437 & 1 & 0.001 & 43.8 & 4 \\
\hline Petitions & 13.291 & 1 & 0.000 & 59.4 & 12 \\
\hline Common positions & 7.336 & 1 & 0.007 & 71.9 & 36 \\
\hline \multicolumn{6}{|l|}{ Slovenia } \\
\hline Government & 0.97 & 1 & 0.755 & 77.3 & 88.5 \\
\hline Political parties & 1.912 & 1 & & 51 & 88 \\
\hline Mass media & 0.697 & 1 & 0.404 & 80 & 64 \\
\hline Social media & 1.262 & 1 & 0.261 & 90.9 & 73.3 \\
\hline Public relations & 1.418 & 1 & 0,234 & 81.8 & 60 \\
\hline Protest & 15.758 & 1 & 0,000 & 72.7 & 7 \\
\hline Petitions & 14.973 & 1 & 0,000 & 74.2 & 6 \\
\hline Common positions & 4.547 & 1 & 0,033 & 76.8 & 36 \\
\hline
\end{tabular}

petitions seem to be more common for idealistic organizations in every country. In every analyzed case, the results for the "protest" and "petitions" variables are statistically significant.

In the next step, I conducted a logistic regression (Table 4.3) to model the probability of a certain event for eight selected lobbying tactics models referring to direct and indirect lobbying strategies. Each object was assigned a probability between 0 and 1, with a sum of one. In the multivariate analysis presented in Table 4.3, coefficients are expressed as the odds ratios of a specific type of lobbying tactic to the comparable odds of the reference category for each variable. Odds ratios above 1 indicate that the particular category is associated with 
TABLE 4.3 Logistic regression model for IG lobbying strategies

\begin{tabular}{|c|c|c|c|c|c|c|c|c|c|c|c|}
\hline & \multicolumn{3}{|c|}{$\begin{array}{l}\text { Model I } \\
\text { Government }\end{array}$} & \multicolumn{3}{|c|}{$\begin{array}{l}\text { Model II } \\
\text { Political Parties }\end{array}$} & \multicolumn{3}{|c|}{$\begin{array}{l}\text { Model III } \\
\text { Uses Mass Media }\end{array}$} & \multicolumn{2}{|c|}{$\begin{array}{l}\text { Model IV } \\
\text { Social Media }\end{array}$} \\
\hline & $\mathrm{B}$ & S.E. & $\begin{array}{r}\text { Odds } \\
\text { rat. }\end{array}$ & B & S.E. & $\begin{array}{r}\text { Odds } \\
\text { rat. }\end{array}$ & B & S.E. & $\begin{array}{r}\text { Odds } \\
\text { rat. }\end{array}$ & B & S.E. \\
\hline $\begin{array}{l}\text { Sectional IGs } \\
\text { Country }\end{array}$ & $1.532^{\star}$ & 0.681 & 4.628 & $1.581^{+}$ & 0.785 & 4.858 & $-0.224^{+}$ & 0.541 & 0.799 & -0.403 & 0.706 \\
\hline $\begin{array}{l}\text { Slovenia } \\
\text { (ref. cat.) }\end{array}$ & 0.00 & 0.00 & 0.00 & 0,00 & 0,00 & 0,00 & 0.00 & 0.00 & 0.00 & 0.00 & 0.00 \\
\hline Poland & 0.481 & 0.813 & 1.627 & 0.259 & 0.560 & 0.772 & 0.121 & 0.758 & 1.129 & -0.300 & 1.315 \\
\hline Czechia & -0.664 & 0.791 & 0.515 & 0.063 & 0.535 & 1.065 & -0.921 & 0.743 & 0.398 & -2.715 & 1.183 \\
\hline $\begin{array}{l}\text { Non-divisible } \\
\text { Goal }\end{array}$ & -1.482 & 0.933 & 0.227 & -0.475 & 0.988 & 0.609 & 0.015 & 0.684 & 1.015 & 0.582 & 0.747 \\
\hline Status Quo & 0.285 & 0.889 & 1.330 & 1.085 & 1.224 & 2.959 & -0.516 & 0.654 & 0.597 & -0.233 & 0.759 \\
\hline Constant & 1.542 & 1.224 & 4.674 & 1.213 & 1.131 & 4.215 & 0.671 & 1.072 & 1.956 & 1.555 & 1.082 \\
\hline $\begin{array}{c}\text { Nagelkerke's } \\
\text { pseudo R }\end{array}$ & & 0.327 & & & 0.383 & & & 0.121 & & 0.117 & \\
\hline Log-likelihood & & 92.934 & & & 77.782 & & & 117.739 & & 115.723 & \\
\hline Observations & & 132 & & & 132 & & & 132 & & 127 & \\
\hline
\end{tabular}

Columns show beta coefficient, standard error and odds ratio. Levels of significance: $+=5 \%, \star=1 \%$ and $\star \star=0.1 \%$ significance.

higher chances than the reference category, whereas values below 1 indicate the opposite. The analysis included the following reference categories: group type (sectional IGs), IG country of origin (Slovenia ref. cat.), goal characteristic (divisible goal ref. cat.), and the status quo.

The group type appears to be the most robust predictor in every tested model of lobbying tactics. In Models I and II, it is visible that sectional groups are several times more likely to use direct lobbying tactics (governmental and parliamentary) than idealistic interest groups. Opposite results were obtained in terms of indirect lobbying tactics, especially in the probability of protest actions (Model VI) and petitions (Model VII). In both models, odds ratios are lower than 1, which means that protest and petitions correspond with lower odds for sectional groups. These activities can be expected more frequently of idealistic organizations. Also, organizations that represent public interests more often encourage other organizations to engage in common actions. Regarding media strategies, our data are also significant for the traditional media variable (Model III) and public relation campaigns (Model IV). Idealistic groups are less likely to use direct lobbying tactics (governmental and parliamentary). The analyzed models suggest in line with hypothesis 1 that idealistic groups indeed rely more intensively on outside lobbying tactics than specific interest organizations, especially in terms of mobilization strategies.

Regarding specific organizational goals, I found significant results in terms of protest activities of the groups. In Model V, groups representing absolute, nondivisible goals are several times more likely to protest than groups that are more able to negotiate the final results. The data also show that groups pursuing divisible 


\begin{tabular}{|c|c|c|c|c|c|c|c|c|c|c|c|c|}
\hline \multirow{3}{*}{$\begin{array}{r}\text { Odds } \\
\text { rat. } \\
0.699\end{array}$} & \multicolumn{3}{|c|}{$\begin{array}{l}\text { Model V } \\
\text { Public Campaigns/PR }\end{array}$} & \multicolumn{3}{|l|}{$\begin{array}{l}\text { Model VI } \\
\text { Protests }\end{array}$} & \multicolumn{3}{|c|}{$\begin{array}{l}\text { Model VII } \\
\text { Petitions }\end{array}$} & \multicolumn{3}{|c|}{$\begin{array}{l}\text { Model VIII } \\
\text { Common Positions }\end{array}$} \\
\hline & B & S.E. & $\begin{array}{r}\text { Odds } \\
\text { rat. }\end{array}$ & B & S.E. & $\begin{array}{r}\text { Odds } \\
\text { rat. }\end{array}$ & B & S.E. & $\begin{array}{r}\text { Odds } \\
\text { rat. }\end{array}$ & B & S.E. & $\begin{array}{r}\text { Odds } \\
\text { rat. }\end{array}$ \\
\hline & $-0.511^{+}$ & 0.533 & 0.600 & $-3.756^{\star \star}$ & 0.870 & 0.231 & $-3.743^{\star}$ & 0.890 & 0.024 & $-1.676^{\star}$ & 0.578 & 0.187 \\
\hline 0.00 & 0.00 & 0.00 & 0.00 & 0.00 & 0.00 & 0.00 & 0.00 & 0.00 & 0.00 & 0.00 & 0.00 & 0.00 \\
\hline 0.741 & -0.501 & 0.737 & 0.606 & 0.382 & 0.801 & 1.465 & 0.224 & 0.955 & 1.252 & 0.451 & 0.754 & 1.570 \\
\hline 0.665 & -0.753 & 0.716 & 0.471 & -1.521 & 0.924 & 0.212 & -1.008 & 0.947 & 0.365 & -0.588 & 0.758 & 0.555 \\
\hline 1.790 & 0.965 & 0.673 & 2.626 & $1.567^{+}$ & 0.709 & 4.791 & 1.923 & 1.195 & 4.957 & 0.225 & 0.697 & 0.555 \\
\hline 0.792 & 0.263 & 0.655 & 1.288 & -0.788 & 1.006 & 0.455 & -0.639 & 0.978 & 0.528 & -0.15 & 0.669 & 0.985 \\
\hline \multirow[t]{4}{*}{4.734} & 0.269 & 1.026 & 1.270 & -0.113 & 1.460 & 0.893 & -0.281 & 1.463 & 0.755 & 1.453 & 1.110 & 4.227 \\
\hline & & 0.119 & & & 0.376 & & & 0.304 & & & 0.266 & \\
\hline & & 118.478 & & & 72.212 & & & 71.658 & & & 03.733 & \\
\hline & & 131 & & & 131 & & & 129 & & & 124 & \\
\hline
\end{tabular}

goals can be expected to seek direct interactions with decision-makers. The results in Models I and II suggest that groups with non-divisible goals are less likely to use direct lobbying tactics, but they are statistically insignificant. Interestingly, I found no significant evidence that status quo groups are more likely to use direct lobbying strategies. The analysis indicates that groups pushing to keep the status quo are more likely to use the administrative and parliamentary strategy and less likely to go public. However, all the results are insignificant. Both analyses partially confirm our second hypothesis that the orientation of IGs goals may influence their lobbying strategies. Groups preferring to keep the status quo or groups with more divisible goals are expected to be more interested in personal contacts with governmental and parliamentary decision-makers, while groups pursuing change and with absolute goals will go public using both mobilization and media strategies.

I also hypothesized (H4) country-specific variations in lobbying strategies. As Poland, Czechia, and Slovenia differ regarding lobbying regimes and election funding, I expected Czech IGs to employ more direct lobbying strategies and Polish and Slovenian groups more diversified approaches. I found little support for this hypothesis. Indeed, it is visible that IGs from Czechia are more likely to lobby political parties than their counterparts from Poland and Slovenia (see Chapter 5 in this volume). Also in terms of mobilization, Czech groups are less likely to protest or conduct petitions and encourage the other groups in their strategies. However, the results are not statistically significant in any of the models. Hence, our theoretical expectations cannot be conclusively confirmed by the data, but they do suggest a tendency in line with hypothesis 4 . 


\section{Conclusions}

This chapter explored various strategies of energy and environmental interest groups in Czechia, Poland, and Slovenia. Addressing a major previous research gap, I focused on three group-related categories such as the group type, goal specificity and country-related factors and analyzed how they affect lobbying behavior. The most important finding is that group type is an important factor determining lobbying strategies (see also Dür \& Mateo, 2013). Idealistic, or public interest, groups much more frequently pursue outsider strategies to impact the policy-making process. This includes protests, petitions and encouraging other actors active in the relevant policy area. However, it has to be emphasized that public interest groups pursue both parliamentary and governmental (inside) strategies as well. Thus, public interest organizations display a broader range of lobbying tactics.

I also found that goals may impact lobbying behavior. Although the evidence is limited, there is a visible trend toward outsider tactics for groups pursuing non-divisible goals such as environmental groups lobbying for a total reduction of fossil fuels. Groups advocating absolute goals more frequently use outsider tactics than groups with more divisible or negotiable goals, which partially confirms the hypothesis regarding goal diversity and lobbying strategies.

In addition, more country-specific differences are also apparent in terms of lobbying strategies among IGs in the three analyzed countries. In the Czech case, there is a slight orientation toward insider tactics. The analyzed sectional groups prefer parliamentary contacts, and there are more pronounced differences in strategies based on group types. In Poland and Slovenia, by contrast, tactics are more spread between group types, with a visible orientation toward inside strategies among sectional IGs. Additionally, it is visible that Polish groups lobby the government more often than groups from Czechia and Slovenia. In every country, public mobilization strategies are more common for idealistic environmental groups.

The present findings offer numerous avenues for future research. For example, it would be interesting to investigate whether there is a relation between the groups' levels of professionalization, longevity, internal resources, and their applied lobbying strategies (see Chapter 7). It would also be very exciting to explore whether differences in lobbying strategies continue to exist between CEE and Western Europe or whether the variations between CEE countries are larger than those between the eastern and western parts of the continent.

\section{Note}

1 e.g., Spolek, Nadace, Nadační fond, Ústav, Obecně prospěšna společnost in Czech; Stowarzyszenie, Fundacja, Zwiazek Zawodowy in Polish; and Društvo, Zavod, Združenie or Ustanova in Slovene and all the words potentially pertaining to the energy and environmental issues in the three languages in all declinations, in the singular and plural (see also Chapters 2 and 3 ). 


\section{References}

Avdagic, S., \& Crouch, C. (2006). Organized Economic Interests: Diversity and Change in an Enlarged Europe. In P. M. Heywood, E. Jones, M. Rhodes, \& U. Sedelmeier (Eds.), Developments in European Politics (pp. 196-215). Houndmills: Palgrave Macmillan

Baumgartner, F., Berry J., Hojnacki M., Leech B., \& Kimball D. (2009). Lobbying and Policy Change: Who Wins, Who Loses, and Why. Chicago, IL: University of Chicago Press.

Berry, J. M. (1977). Lobbying for the People: The Political Behavior of Public Interest Groups. Princeton, NJ: Princeton University Press.

Beyers, J. (2004). Voice and Access: Political Practices of European Interest Associations, European Union Politics 5(2), 211-240. https://doi.org/10.1177/1465116504042442

Beyers, J., Braun C., Marshall D., \& De Bruycker, I. (2014). Let's Talk! On the Practice and Method of Interviewing Policy Experts, Interest Groups \& Advocacy 3(2), 174-187. https://doi.org/10.1057/iga.2014.11

Beyers, J., Eising, R., \& Maloney, W. (2008). Researching Interest Group Politics in Europe and Elsewhere: Much We Study, Little We Know? West European Politics 31(6), 1103-1128. https://doi.org/10.1080/01402380802370443

Binderkrantz, A. S. (2005). Interest Group Strategies: Navigating between Privileged Access and Strategies of Pressure, Political Studies 53(4), 694-715. https://doi. org/10.1111\%2Fj.1467-9248.2005.00552.x

Binderkrantz, A. S. (2008). Different Groups, Different Strategies: How Interest Groups Pursue Their Political Ambitions, Scandinavian Political Studies 31(2), 173-200. https:// doi.org/10.1111/j.1467-9477.2008.00201.x

Binderkrantz, A. S., Christiansen, P. M., \& Pedersen, H. H. (2015). Interest Group Access to the Bureaucracy, Parliament, and the Media, An International Journal of Policy, Administration, and Institutions 28(1), 95-112. https://doi.org/10.1111/gove.12089

Binderkrantz, A. S., \& Krøyer, S. (2012). Customizing Strategy: Policy Goals and Interest Group Strategies, Interest Groups \& Advocacy 1(1), 115-138. https://doi.org/10.1057/ iga.2012.6

Bohle, D., \& Greskovits, B. (2012). Capitalist Diversity on Europe's Periphery. Ithaca, NY: Cornell University Press.

Brennan, G. (2009). Climate Change: A Rational Choice Politics View, The Australian Journal of Agriculture and Resource Economics 53(3), 309-326. https://doi. org/10.1111/j.1467-8489.2009.00457.x

Bruycker, I. (2015). Pressure and Expertise: Explaining the Information Supply of Interest Groups in EU Legislative Lobbying. Journal of Common Market Studies 54(3), 599-616. https://doi.org/10.1111/jcms.12298

Dellmuth, L. M., \& Tallberg, J. (2017). Advocacy Strategies in Global Governance: Inside versus Outside Lobbying, Political Studies 65(3), 705-723. https://doi. org $/ 10.1177 / 0032321716684356$

Dunleavy, P. (1991). Democracy, Bureaucracy and Public Choice. Economic Explanations in Political Science. New York: Harvester/Wheatsheaf.

Dür, A. (2008). Interest Groups in the European Union: How Powerful Are They? West European Politics 31(6), 1212-1230.

Dür, A., \& De Bièvre, D. (2007). The Question of Interest Group Influence, Journal of Public Policy 27(1), 1-12.

Fink-Hafner, D. (2011). Interest Representation and Post-Communist Parliaments over Two Decades, The Journal of Legislative Studies 17(2), 215-233. https://doi.org/10.1080/ 13572334.2011.574027 
Gais, T. L., \& Walker Jr, J. L. (1991). Pathways to Influence in American Politics. In J. L. Walker, Jr. (Ed.), Mobilizing Interest Groups in America (pp. 103-121). Ann Arbor: University of Michigan Press.

Gallai, S., Döme, Z., Molnár, B., \& Reich, J. (2015). What Makes Them Successful?: Influential Interest Groups in Hungary (1990-2014), Europe-Asia Studies 67(9), 14691486. https://doi.org/10.1080/09668136.2015.1088514

Grant, W. (2000). Pressure Groups and British Politics. London: MacMillan Press Ltd.

Howard, M. M. (2003). The Weakness of Civil Society in Post-Communist Europe (2nd ed.). Cambridge: Cambridge University Press.

Klüver, H., \&; Saurugger, S. (2013). Opening the Black Box: The Professionalization of Interest Groups in the European Union, Interest Groups \& Advocacy 2(2), 185-205. https://doi.org/10.1057/iga.2013.2

Kubik, J. (2005). How to Study Civil Society, East European Politics and Societies 19(1), 105-120. https://doi.org/10.1177/0888325404272556.

Maloney, W. A., Jordan, G., \& McLaughlin, A. M. (1994). Interest Groups and Public Policy: The Insider/Outsider Model Revisited, Journal of Public Policy 14(1), 17-38. https://doi.org/10.1017/S0143814X00001239.

McGrath, C. (2008). The Development and Regulation of Lobbying in the New Member States of the European Union, Journal of Public Affairs 8(1), 15-32. https://doi. org/10.1002/pa.284

Meyer, D., S., \& Imig, D. R. (1993). Political Opportunity and the Rise and Decline of Interest Group Sectors, The Social Science Journal 30(3), 253-270.

Olson, M. (1965). The Logic of Collective Action: Public Goods and the Theory of Groups. Harvard Economic Studies: v. 124. Cambridge, MA: Harvard University Press.

Schattschneider, E. E. (1960). The Semisovereign People: A Realists View at Democracy in America. New York: Holt, Rienhart and Winston.

Šimral, V. (2015). The Funding and Oversight of Political Parties and Electoral Campaigns in Central and Eastern Europe. Prague: Frank Bold.

Skoczkowski, T., Bielecki S., Węglarz A., Włodarczak M., \& Gutowski P. (2018). Impact Assessment of Climate Policy on Poland's Power Sector, Mitigation and Adaptation Strategies for Global Change 23, 1303-1349.

Sprūds, A. (2010). Latvian Energy Policy: Towards a Sustainable and Transparent Energy Sector. Riga: Soros Foundation Latvia.

Stewart J. D. (1958). British Pressure Groups. Oxford: Clarendon.

Streeck, W., \& Kenworthy, L. (2003) Theories and Practices of Neocorporatism. In Janoski, T., Alford, R., Hicks, A., Schwartz, M. (Eds.), The Handbook of Political Sociology, Cambridge: Cambridge University Press, 441-460. https://doi.org/10.1017/ CBO9780511818059.

Wilson, J. Q. (1973). Political Organizations. New York: Basic Books, Inc.

Živčič, L., \& Tkalec, T. (2019). Slovenia: Focus on Energy Efficiency, Community Energy Projects and Energy Poverty. In F. Fahy, G. Goggins, \& C. Jensen (Eds.), Energy Demand Challenges in Europe. Cham: Palgrave Pivot. https://doi.org/10.1007/9783-030-20339-9_9 